\title{
Evaluation of Pharmacological Properties of Caesalpinia bonducella Seed and Shell Extract
}

\author{
Vigasini Subbiah, Pannaga Nagaraja, Priya Narayan*, Holenarasipur Gundu Rao Nagendra
}

Vigasini Subbiah, Pannaga Nagaraja, Priya Narayan*, Holenarasipur Gundu Rao Nagendra

Department of Biotechnology, Sir M. Visvesvaraya Institute of Technology, Hunasamaranahalli, Bangalore- 562157, Karnataka, INDIA.

Correspondence

Dr. Priya Narayan

Department of Biotechnology, Sir M Visvesvaraya Institute of Technology, Hunasamaranahalli, Bangalore- 562157, Karnataka, INDIA.

Phone no : +919880993818

E-mail: brunaboy@gmail.com

History

- Submission Date: 02-09-2018.

- Review completed: 06-11-2018;

- Accepted Date: 20-11-2018

DOI : 10.5530/pj.2019.1.25

Article Available online

http://www.phcogj.com/v11/i1

Copyright

(C) 2019 Phcog.Net. This is an openaccess article distributed under the terms of the Creative Commons Attribution 4.0 International license.

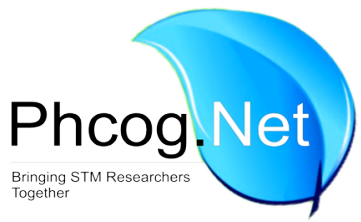

\begin{abstract}
Background: Caesalpinia bonducella L. is a medicinal plant belonging to the family Caesalpiniaceae. It is a prickly shrub widely distributed all over the world especially in Indian tropical regions such as Kerala, Andaman and Nicobar Islands and Sri Lanka. There are claims that its leaves or seeds/ seed kernel possess antipyretic, antidiuretic, antibacterial, antiviral, antiestrogenic and antidiabetic activities. Due to the above properties several preparations of the plant were used in folk medicine. Materials and Methods: The aqueous extract of Caesalpinia bonducella nut containing the seed and the shell, has been evaluated for qualitative analysis of secondary metabolites (tannis, flavonoids, alkaloids, saponins, coumarins, quinone and phenols), in-vitro anti-inflammatory, anti-diabetic assay, antioxidant, antimitotic and antimicrobial activity. The studies were carried out using HRBC membrane stabilization, inhibition of alpha amalyse enzyme, DPPH method, green gram growth inhibition, agar diffusion method respectively. Results: Our results indicate the presence of Alkaloids, Flavanoids and Saponins. We report in our study the antidiabetic, anti-inflammatory, anti-oxidant, anti-microbial and antimitotic activity of Caesalpinia bonducella.

Key words: Anti-inflammatory, Anti-diabetic, Anti-mitotic, Anti-oxidant, Caesalpinia bonducella.
\end{abstract}

\section{INTRODUCTION}

Caesalpinia bonducella L. also known as "fever nut" Bonduc nut and Nicker nut belongs to the family of Caesalpiniaceae and has been reported in Folklore medicine and ancient Ayurveda scriptures. ${ }^{1-3}$ C. bonducella has been known to be used by Siddha practitioners in Malabar regions for psoriasis treatment. ${ }^{1}$ C. bonducella is a large prickly shrub known to be a native of South India, Burma and Ceylon, particularly along the sea coast and up to $2500 \mathrm{ft}$. in hilly regions. ${ }^{4}$ It is reported in literature that most parts of the plant has therapeutic properties, but much has been studied with the seed and shell..$^{5-6}$ The alkaloids in Caesalpinia bonducella $\mathrm{L}$ are known to be found in shell, seed and twigs, the predominant one being Natin. The active molecule, Bonducin is reported to be present in the seed as a powerful glycoside. Saponins and terpenoids are also known to be found in seed. ${ }^{7}$ The shell is known to contain fatty oil, starch, sucrose, phytosterols, stearic, palmitic, oleic, linoceric, linolenic and a mixture of unsaturated acid of low molecular weights. The protein and amino acid content varies from 7.430 to $25.346 \%{ }^{8}$ The seeds are reported to have anti-diabetic properties. Type 2 diabetes, a chronic metabolic disorder affects people of all ages across the globe. This disease is characterized by increase in the blood glucose level which may be multifactorial. The primary cause is the decrease or lack of insulin production. The treatment regimen for Type 2 Diabetes is mainly to prevent breakdown of carbohydrates to glucose and preventing its diffusion into the intestinal membrane into blood stream. The abundance of natural resources in India and the rising numbers of Diabetes patients will pave the way for newer medications/adjunct therapies to manage the disorder. ${ }^{9}$ Inflammation is often associated with pain and involves the increase of vascular permeability, increase of protein denaturation and membrane alteration. When the cell undergoes injury, inflammation of tissue becomes a defensive response characterized by redness, pain, heat and swelling and loss of function in the injured area. The management of inflammation related diseases is of concern and may have to be addressed using plant extracts. ${ }^{10}$ The plant is also known to possess antioxidant, ${ }^{11}$ antifilarial activity, ${ }^{12}$ anticonvulsive activity $^{13}$ and anti-microbial activity, ${ }^{14}$ antimalarial activity $^{15}$ antitumor activity ${ }^{16}$ anti-ulcer activity ${ }^{17}$ immunomodulatory activity ${ }^{18}$ and anticataract activity. ${ }^{19}$ With the rising problems of Diabetes, inflammation related diseases and cancers; there is a need to address the issues using alternate therapy. As there is limited study on the aqueous extract of Caesalpinia bonducella L, shell and seed we have evaluated their pharmacological properties.

\section{MATERIALS AND METHODS}

\section{Plant Material}

Nuts of the C. bonducella were collected from the local market in Bengaluru, Karnataka, India. The 
seed and shell extract was prepared by following the method of Shukla et $a l .{ }^{20}$ The nuts were shade dried, coarsely powdered and sieved to get a uniform powder. The sample was extracted in water using Soxhlet extractor. The crude extract obtained was evaporated and concentrated.

\section{Phytochemical analysis}

Phytochemical analysis was carried out for saponins, flavonoids, quinones, alkaloids and tannins were performed as described by Maria Shabbir et al. ${ }^{21}$ Wagner's reagents was used for alkaloid, foam test for saponins, lead acetate test for flavonoids, Braemer's test for tannins, Sulphuric acid test for quinones. All these experiments were carried out for water extract for seed and shell individually.

\section{In-vitro Anti Inflammatory Assay}

The activity was carried out by the method of Gandhisan et al. ${ }^{22}$ The blood was collected from healthy volunteers and mixed with equal proportion of Alsever solution ( $2 \%$ dextrose, $0.8 \%$ sodium citrate, $0.5 \%$ citric acid and $0.42 \% \mathrm{NaCl}$ ). The sample was centrifuged at 3,000 rpm and cells washed with saline.

Extract concentrations of 200, 400, 600, 800 and $1000 \mu \mathrm{g} / \mathrm{ml}$ was prepared using distilled water. To this $1 \mathrm{ml}$ of extract, $1 \mathrm{ml}$ of phosphate buffer, $2 \mathrm{ml}$ hypo saline and $0.5 \mathrm{ml}$ of HRBC suspension were added. It was incubated at $37^{\circ} \mathrm{C}$ for $30 \mathrm{~min}$ and centrifuged at 3,000 rpm for $20 \mathrm{~min}$. The percentage of HRBC membrane stabilization or protection was calculated by using the following Formula with Aspirin $(1 \mathrm{mg} / \mathrm{ml})$ as reference standard drug

$\%$ protection $=100$ - (Optical density of drug treated sample/ Optical density of control) x100

\section{Anti-Diabetic Assay}

The anti-diabetic assay was carried out using $100 \mu \mathrm{l}$ of $(500,1000 \mu \mathrm{g} / \mathrm{ml})$ plant extracts and $200 \mu \mathrm{l}$ of amylase and incubated at $37^{\circ} \mathrm{C}$ for $20 \mathrm{~min}$. To the reaction mixture $1 \%$ starch $(100 \mu \mathrm{l})$ was added and incubated at $37^{\circ} \mathrm{C}$ for $10 \mathrm{~min}$. The reaction was arrested by adding $200 \mu \mathrm{l}$ DNSA and keeping in a boiling water bath for $5 \mathrm{~min}$. The reaction mixture was diluted with $2.2 \mathrm{ml}$ of water and absorbance read at $540 \mathrm{~nm}$ against blank. ${ }^{23}$

\section{Determination of DPPH free radical scavenging activity}

The antioxidant property was assessed using Ascorbic acid as the standard and DPPH (1,1-diphenyl-2-picrylhydrazyl) as control. 100 $\mu$ l of the extract was taken with $3 \mathrm{ml}$ of DPPH solution and incubated for $30 \mathrm{~min}$. The absorbance was read at $517 \mathrm{~nm}$ and the ability of the DPPH to scavenge free radical was calculated using the formula

$$
\text { DPPH scavenged }(\%)=\{(\mathrm{Ac}-\mathrm{At}) / \mathrm{Ac}\} \times 100
$$

Where Ac is the absorbance of the control reaction and At is the absorbance in presence of the sample. The antioxidant activity of the extract was expressed as $\mathrm{IC}_{50}$ which is the concentration in mg of dry material per $\mathrm{ml}(\mathrm{mg} / \mathrm{ml})$ that inhibits the formation of DPPH radicals by $50 \%$. Each value was determined from regression equation. ${ }^{24}$

\section{Anti-mitotic activity}

Green gram seeds of equal weight were germinated in $500 \mu \mathrm{l}$ of $(10,20$, $30,40 \mathrm{mg} / \mathrm{ml}$ ) plant extracts in a 24 -well microtiter plate. Seeds germinated in distilled water served as the control and that in drug doxorubicin as the standard (Kumar and Singhal, 2009). For the morphological study, the length of the radical was observed. Experiment was performed in triplicates. ${ }^{25}$

\section{Anti-Microbial Activity}

The antimicrobial activity of the extract was assessed using Staphylococcus aureus, Candida albicans and Mycobacterium smegmatis by the agar diffusion method. The agar diffusion method was used to evaluate the anti-microbial activity of the plant extract. $30 \mathrm{ml}$ of nutrient agar was poured into petri plates containing $100 \mu$ l of microorganisms (McFarlands Number 5). After $24 \mathrm{~h}$ the zone of inhibition was measured and compared using Streptomycin and Candid B as the standards for bacteria and fungi respectively.

\section{RESULTS}

\section{Phytochemical analysis}

The qualitative analysis of the secondary metabolites like tannins, flavonoids, alkaloids etc., was done for water extract of C. bonducella and the results tabulated in Table 1. Our results indicate the presence of flavanoids and alkaloids in both parts of the nut. The seed and shell was rich in saponins indicating its therapeutic value.

\section{In-vitro Anti Inflammatory Activity}

The HRBC membrane stabilization method was used to study the antiinflammatory activity. The prevention of hypo tonicity induced HRBC membrane lysis was taken as measure in estimating the anti-inflammatory property. The $\%$ protection is indicated in Figure 1 and depicted in Table 2. The maximum anti-inflammatory activity of seed and shell was found to

Table 1: Phytochemical analysis of water extract of seed and shell. ' + ' indicates the presence of the metabolites and '-'indicates the absence of the metabolites. '+++' indicates higher concentration of metabolites.

\begin{tabular}{ccc}
\hline & Aqueous Extract & \\
\hline & Seed & Shell \\
\hline Tannins & - & - \\
Flavanoids & + & + \\
Alkaloids & + & + \\
Saponins & +++ & ++ \\
Coumarins & - & - \\
Quinones & - & - \\
Phenols & - & - \\
\hline
\end{tabular}

\section{ANTI-INFLAMMATORY ACTIVITY} -SEED —SHELL $\square$ ASPIRIN

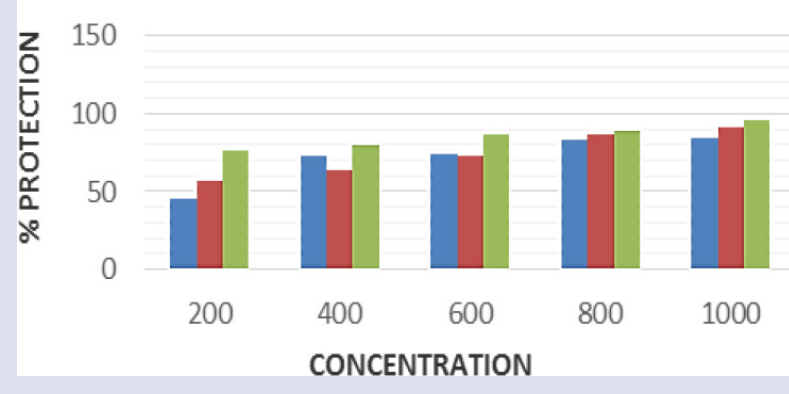

Figure 1: In-vitro Anti- inflammatory activity of $C$. bonducella aqueous extract. (source: Personal collection) 
Table 2: In vitro Anti- inflammatory activity of $C$. bonducella aqueous extract.

\begin{tabular}{cccccc}
\hline \% Protection & 200 & 400 & 600 & 800 & 1000 \\
& $\mu \mathrm{g} / \mathrm{ml}$ & $\mu \mathrm{g} / \mathrm{ml}$ & $\mu \mathrm{g} / \mathrm{ml}$ & $\mu \mathrm{g} / \mathrm{ml}$ & $\mu \mathrm{g} / \mathrm{ml}$ \\
\hline \multirow{2}{*}{ Seed } & $44.927 \pm$ & $72.463 \pm$ & $73.913 \pm$ & $82.608 \pm$ & 84.37 \\
& 4.03 & 2.366 & 4.81 & 4.098 & \pm 2.19 \\
Shell & $56.521 \pm$ & $63.768 \pm$ & 72.463 & $86.956 \pm$ & $91.304 \pm$ \\
& 6.072 & 1.366 & \pm 3.414 & 3.56 & 4.054 \\
Aspirin & $76.811 \pm$ & $79.71 \pm$ & $86.956 \pm$ & $88.405 \pm$ & $95.652 \pm$ \\
& 0.682 & 1.18 & 4.381 & 4.782 & 4.652 \\
\hline
\end{tabular}

Table 3: Inhibition of $a$-amylase by aqueous extract of $C$. bonducella.

\begin{tabular}{ccc}
\hline$\%$ Inhibition & $500 \mu \mathrm{g} / \mathrm{ml}$ & $1000 \mu \mathrm{g} / \mathrm{ml}$ \\
\hline Shell & $31.818 \%$ & $78.947 \%$ \\
Seed & - & $47.36 \%$ \\
Glycomet GP2(Standard drug) & $59.20 \%$ & $80.97 \%$ \\
\hline
\end{tabular}

Table 4: \% antiradical activity of $C$. bonducella aqueous extract.

\begin{tabular}{cccccc}
\hline $\begin{array}{c}\text { Anti -radical } \\
\text { activity }\end{array}$ & 200 & 400 & 600 & 800 & 1000 \\
\hline Shell (in \%) & $41.17 \pm$ & $55.88 \pm$ & $58.82 \pm$ & $61.76 \pm$ & $61.76 \pm$ \\
& 6.355 & 1.385 & 1.3 & 1.385 & 1.385 \\
Seed (in \%) & - & - & - & - & - \\
Standard (in \%) & $74.28 \pm$ & $80 \pm$ & $85.71 \pm$ & $87.14 \pm$ & $88.571 \pm$ \\
& 2.75 & 2.696 & 1.16 & 1.78 & 2.34 \\
\hline
\end{tabular}

be $84.37 \%$ and $91.304 \%$ respectively at $1000 \mu \mathrm{g} / \mathrm{ml}$ and the $\%$ protection of shell was close to that of standard drug aspirin.

\section{Anti-Diabetic Assay}

Inhibition of $a$-amylase is considered a strategy for the treatment of disorders in carbohydrate uptake such as diabetes and obesity. $\alpha$-amylase activity can be measured in-vitro by hydrolysis of starch in presence of $\alpha$-amylase enzyme. Glycomet GP2 was used as the standard drug. The results of the Anti- diabetic activity is tabulated in Table 3. The maximum activity was at a concentration of $1000 \mu \mathrm{g} / \mathrm{ml}$ and shell showed a better antidiabetic activity compared to the seed. It is also observed that the antidiabetic activity of the shell extract is close to the standard value.

\section{Determination of Antioxidant Efficacy by DPPH Method}

1,1-Diphenyl-2-picrylhydrazyl is a stable free radical with red colour (absorbed at 550nm). If free radicals have been scavenged, DPPH will change its colour to yellow. This assay uses this character to show free radical scavenging activity. The seed did not show any anti-oxidant activity. $\%$ antiradical activity of the sample is indicated in Table 4 . The $\mathrm{IC}_{50}$ value was calculated and represented in Figure 2.

\section{Anti-Mitotic Assay}

Seeds of equal weight were taken in each well and $500 \mu \mathrm{l}$ of the extract of various concentrations were added. The dry weight of the seeds was taken after $24 \mathrm{~h}$ and $48 \mathrm{~h}$. Doxorubicin $(1 \mathrm{mg} / \mathrm{ml})$ was used as the standard drug and it showed 20\% inhibition after $24 \mathrm{~h}$ and $51.1 \%$ inhibition after $48 \mathrm{hrs}$. Shell did not show any anti-mitotic activity. The results are tabulated in Table 5. Maximum inhibition of growth was found at $40 \mathrm{mg} / \mathrm{ml}$ of seed extract as seen in Figure 3 and 4.

\section{\% Anti radical activity of shell}

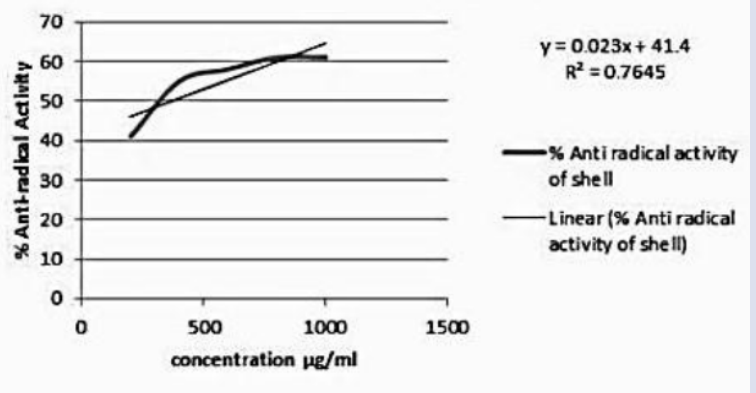

Figure 2: $I C_{50}$ value of the aqueous extract of shell. The $I C_{50}$ was found to be $350.638 \mu \mathrm{g} / \mathrm{ml}$ for the shell extract. (source: Personal collection)

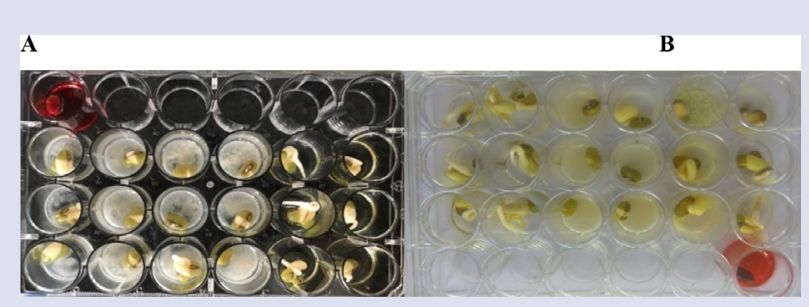

Figure 3: A: Seed germination at $24 \mathrm{~h}$; B: Seed germination at $48 \mathrm{~h}$. (source: Personal collection)

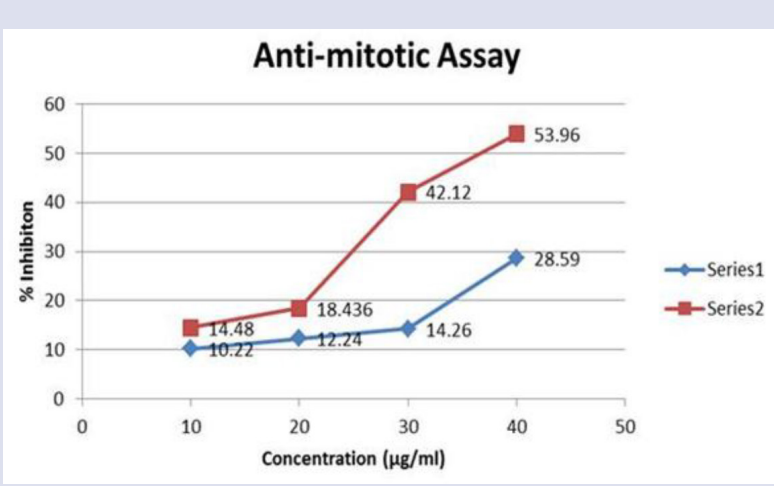

Figure 4: Antimitotic assay for C. bonducella aqueous extract. (source: Personal collection)

Table 5: \% inhibition of seed growth, shell extract did not show inhibition of seed growth.

\begin{tabular}{ccccc}
\hline Seed & $10 \mathrm{mg} / \mathrm{ml}$ & $20 \mathrm{mg} / \mathrm{ml}$ & $30 \mathrm{mg} / \mathrm{ml}$ & $40 \mathrm{mg} / \mathrm{ml}$ \\
\hline $24 \mathrm{~h}$ & $10.22 \%$ & $12.24 \%$ & $14.26 \%$ & $28.59 \%$ \\
$48 \mathrm{~h}$ & $14.48 \%$ & $18.436 \%$ & $42.12 \%$ & $53.96 \%$ \\
\hline
\end{tabular}


Vigasini, et al.: Pharmacological Properties of Bonduc Nut

Table 6: Zone of inhibition of the C. bonducella crude extract.

\begin{tabular}{cccccc}
\hline $\begin{array}{c}\text { Zone of } \\
\text { inhibition }\end{array}$ & $\begin{array}{c}\text { Crude } \\
\text { extract } \\
\text { of shell }\end{array}$ & $\begin{array}{c}10 \mathrm{mg} / \mathrm{ml} \\
\text { of shell } \\
\text { extract }\end{array}$ & $\begin{array}{c}\text { Crude } \\
\text { extract } \\
\text { of Seed }\end{array}$ & $\begin{array}{c}10 \mathrm{mg} / \mathrm{ml} \\
\text { of seed } \\
\text { extract }\end{array}$ & standard \\
\hline $\begin{array}{c}\text { Staphylococcus } \\
\text { aureus }\end{array}$ & $11 \mathrm{~mm}$ & - & - & - & $\begin{array}{c}12 \mathrm{~mm} \\
\text { (Streptomycin) }\end{array}$ \\
$\begin{array}{c}\text { Candida } \\
\text { albicans }\end{array}$ & $10 \mathrm{~mm}$ & - & - & - & $10 \mathrm{~mm}$ \\
$\begin{array}{c}\text { Mycobacterium } \\
\text { smegmatis }\end{array}$ & $11.5 \mathrm{~mm}$ & - & - & - & $\begin{array}{c}\text { (Candid B) } \\
12 \mathrm{~mm}\end{array}$ \\
\hline
\end{tabular}

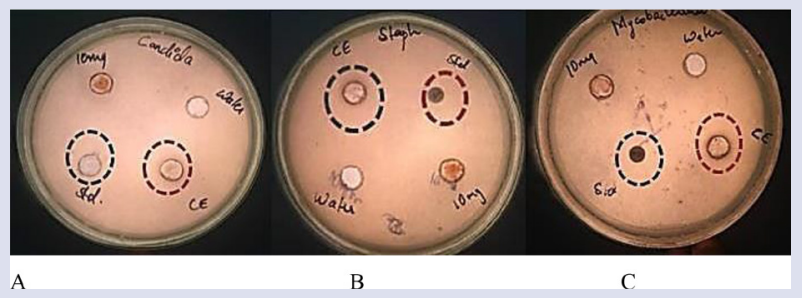

Figure 5: A: Zone of inhibition for Candida albicans B: Zone of inhibition for Staphylococcus aureus C: Zone of inhibition for Mycobacterium smegmatis.

(source: Personal collection)

\section{Anti-Microbial Studies}

The antimicrobial activity was assessed for the aqueous extract of shell using the agar diffusion method. The zone of inhibition was measured using streptomycin and Candid B as the standard for bacteria and fungi respectively. The results are indicated in Table 6 and Figure 5. Our results indicate that the crude extract of the sample showed a better antimicrobial activity, indicating its use as a topical application.

\section{DISCUSSION AND CONCLUSION}

Many herbal remedies have been employed in various medical systems for the treatment and management of different diseases. The plant Caesalpinia bonducella (syn: Caesalpinia crista Linn.) has been used in different system of traditional medication for the treatment of diseases and ailments of human beings. ${ }^{26}$ Phytochemicals are a class of molecules found predominantly in tea, grapes, berries, cocoa and other plants. These are known to have diverse pharmacological properties. ${ }^{27}$ Though they do not have any nutritive value the protective and disease preventing properties have been well explored. It is in this context that the study of the pharmacological properties of Caesalpinia bonducella was conceived. ${ }^{28}$ Flavonoids are found in fruits, nuts, grains and vegetables and used extensively to study their effect on heart diseases and cancer. Flavanoids are known to exhibit anti-inflammatory and anti-oxidant and anti-microbial properties. This is in accordance with our results wherein the flavonoid content in the seed and shell extract are moderately high. Taken together, these results indicate the anti-oxidant and anti-inflammatory properties of Bondoc nut. Our results reveal the antimitotic activity of the seed extract and hence may be exploited further for the treatment of cancer. Our experimental results also reveal the inhibition of $\alpha$ amylase activity, indicating that the plant may be used in anti-diabetic therapy. Further, our results indicate the presence of Alkaloids, Flavanoids and Saponins. We report in our study the antidiabetic, anti-inflammatory, anti-oxidant, anti-microbial and anti-mitotic activity. Taken together our results indicate the use of $C$ bonducella as an adjunct therapy for inflammation and diabetes.

\section{ACKNOWLEDGEMENT}

We would like to thank the Department of Biotechnology, Sir M. Visvesvaraya Institute of Technology and Sri KET.

\section{CONFLICT OF INTEREST}

The author declare no conflict of interest.

\section{ABBREVIATIONS}

DPPH: 1,1-diphenyl-2-picrylhydrazyl.

\section{REFERENCES}

1. Manikandaselvi S, Vadivel V, Brindha P. Caesalpinia bonducella L. A nutraceutical plant. Journal of Chemical and Pharmaceutical Research. 2015;7(12):137-42.

2. Kannur DM, Paranjpe MP, Sonavane LV, Dongre PP, Khandelwal KR. Evaluation of Caesalpinia bonduc seed coat extract for anti-inflammatory and analgesic. J Adv Pharm Technol Res. 2012;3(3):171-5.

3. Khare CP. Indian Medicinal Plants: An Illustrated Dictionary. New York: Springer Science+ Business Media. 2007;107-8.

4. The Wealth of India: A Dictionary of Indian Raw Materials and Industrial Products: Raw Materials and Industrial Products, Part II. In "C." B. N. Sastri. New Delhi, India: Council of Scientific and Industrial Research. 1950;2:1951.

5. Ghatak NG. Chemical examination of kernals of the seeds of Caesalpinia bonducella. Proc Indian Acad Sci. 1934;4:141.

6. Iyenger MA, Pendse GS. Anti-diarrheal activity of the nuts of Caesalpinia bonducella Flem. Indian J Phar. 1965;27:307.

7. Tummin KMC. Chemical examination of seeds of Caesaipinia bonducella Fiem.

8. J Indian Chem Soc. 1930;7:207.

9. Chopra RN, Chopra IC, Verma BS. Supplement to Glossary of Indian Medicinal Plants, Publication and Information Directorate (CSIR), New Delhi. 1969.

10. Vedavyasa S, Ahamad RN. Antihyperlipidemic Effect of Alcoholic Seed Extract of Caesalpinia Bonduc In Alloxan Induced Diabetic Male Albino Rats. International Journal of Diabetic and Endocrinology. 2015;4(1):1-9.

11. Shukla S, Mehata A, Mehata P, Vyas SP, Shukla S, Bajpai VK. Studies on antiinflammatory, antipyretic and analgesic properties of Caesalpinia bonducella F. seed oil in experimental animal models. Food and Chemical Toxicology. 2012;48(1):61-4

12. Sachan NK, Verma S, Sachan AK, Hussain A. An investigation of antioxidant activity of Caesalpinia bonducella seeds. Annals of Pharmacy and Pharmacological Sciences. 2010;1(2):88-91.

13. Gaur RL, Sahoo MK, Dixit S, Fatma N, Rastogi S, Kulshreshtha DK, et al. Antifilarial activity of Caesalpinia bonducella against experimental filarial infection. Indian Journal of Medical Research. 2008;128(1):65-70.

14. Ali A, Venkat Rao N, ShalamM, Shivaraj GT, Shantakumar SM. Anticonvulsive effect of seed extract of Caesalpinia bonducella. Iranian Journal of Pharmacology and Therapeutics. 2009;8(2):51-5.

15. Billah MM, Islam $R$, Khatun $H$, Parvin S, Islam E, Islam SA, et al. Antibacterial antidiarrhoel and cytotoxic activities of methanol extract and its fractions of Caesalpinia bonducella (L) Roxb leaves. The Official Journal of the International Society for Complementary Medicine Research. 2013;13(1):101.

16. Irshad S, Mehata A, Mehata P. Antimalarial activity of three Pakistan medicinal plants. Pakistan Journal of Pharmaceuticals Sciences. 2011;24(4):589-91.

17. Gupta M, Mazumder UK, Kumar RS, SivakumarT, Vamsi ML. Anti-tumor activity and antioxidant status of Caesalpinia bonducella against Ehrlich ascites carcinoma 2in Swiss albino mice. Journal of Pharmacological Science. 2004;94(2):177-84.

18. Ansari JA, Ahmad S, Jameel M. Effect of Caesalpinia bonducella L. on ulcer and gastric secretions in pylorus legated rat model. Journal of Drug Delivery and Therapeutics. 2012;2:102-4

19. Shukla S, Mehta A, John J, Mehta P, Vyas SP, Shukla S. Studies on immunomodulatory activities of ethanolic extract of Caesalpinia bonducella seeds. Journal of Ethnopharmacology. 2009;125(2):252-6.

20. Kurmi $\mathrm{P}$, Konwar M, Das S. In vitro anticataract activity of ethanolic extract of seed kernel of Caesalpinia bonduc on goat. Pharma Science Monitor 2015;6(1):244-53.

21. Shukla S, Mehta A, John J, Singh S, Mehta P, Vyas SP. Antioxidant activity and total phenolic content of ethanolic extract of Caesalpinia bonducella seeds. Food Chem Toxicol. 2009;47(8):1848-51.

22. Shabbir M, Khan MR, Saeed N. Assessment of phytochemicals, antioxidant, anti-lipid peroxidation and anti-hemolytic activity of extract and various fractions of Maytenus royleanus leaves. BMC Complement Altern Med. 2013;13(1):143. 
23. Sangeetha G, Vidhya R. In vitro anti-inflammatory activity of different parts of Pedalium murex (L.). International Journal of Herbal Medicine. 2016;4:31-6.

24. Abanish R, Mahalingam G. The in-vitro antidiabetic activity of Phoenix roebelenii leaf extract. International Journal of Green Pharmacy. 2017;11(01).

25. Banerjee A, Maji B, Mukherjee S, Chaudhuri K, Seal T. In vitro Antidiabetic and Anti-oxidant Activities of Methanol Extract of Tinospora Sinensis. Journal of Applied Biology and Biotechnology. 2017;5(03):061-7.

26. Jose GM, Anitha R, Kurup GM. Antioxidant and antimitotic activities of sulfated polysaccharide from marine brown algae Padina tetrastromatica. Journal of
Phytology. 2015;7:39-51.

27. Moon K, Khadabadi SS, Deokate UA, Deore SL. Caesalpinia bonducella F-an Overview. Report and Opinion. 2010;2(3):83-90.

28. Ono K, Li L, Takamura Y, Yoshiike Y, Zhu L, Han F, et al. Phenolic compounds prevent amyloid $\beta$-protein oligomerization and synaptic dysfunction by site specific binding. J Biol Chem. 2012;287:14631-43.

29. Hasler CM, Blumberg JB. Symposium on Phytochemicals: Biochemistry and Physiology. J Nutr. 1999;129:756-7.

\section{GRAPHICAL ABSTRACT}

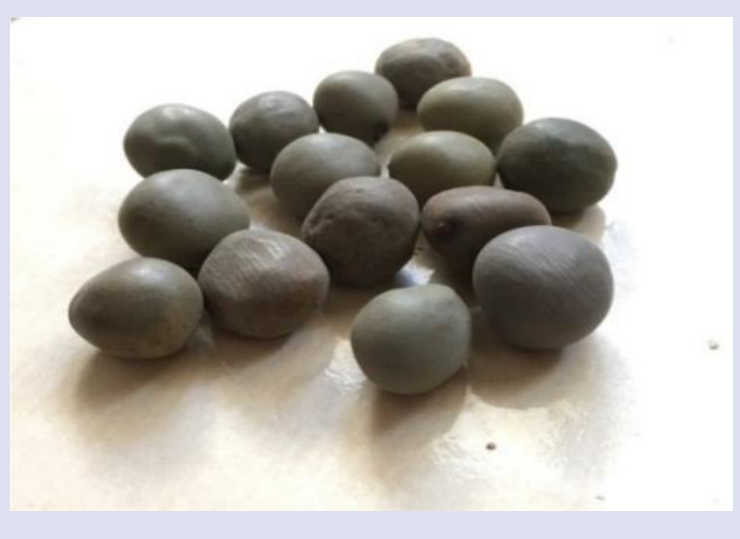

\section{SUMMARY}

- The study reported the presence of various Alkaloids, Flavonoids and Saponins in the seed/shell of Caesalpinia bonducella L. Due to the presence of these bioactive compounds, the seed and the shell extracts showed antidiabetic, anti-inflammatory, anti-oxidant, anti-microbial and anti-mitotic activity. $C$ bonducella can thus be used as an adjunct therapy for inflammation and diabetes. The use of $C$ bonducella seed extract for the treatment of cancer requires further research.

Cite this article: Subbiah V, Nagaraja P, Narayan P, Nagendra HG. Evaluation of Pharmacological Properties of Caesalpinia bonducella Seed and Shell Extract. Pharmacog J. 2019;11(1):150-4. 